\title{
BREXIT AND THE FUTURE OF ENGLISH LAW
}

David Lloyd Jones*

Sir David Lloyd Jones was the 2017 Victoria University Law Dean's Fellow. The following is a revised version of the lecture given at Victoria University of Wellington on 23 August 2017 on the likely impact of Brexit on English law. It is based on the information available at that date.

\section{INTRODUCTION}

The United Kingdom's membership of what was originally the European Economic Community (EEC) and later became the European Union (EU) spans almost exactly my life in the law so far. The winter of 1971-1972 was a particularly bitter one and I well remember, as a law student in Cambridge, sitting hunched over a gas fire in my student digs, listening to reports on the radio of parliamentary debates on what became the European Communities Act 1972 (UK). Later as a barrister I appeared frequently before the European Court of Justice in Luxembourg and courts in England and Wales representing both the United Kingdom and the European Commission. Later still, I sat as a judge on many cases concerning EU law. Now, 45 years after the United Kingdom's accession, its preparations to leave the Union dominate public and legal life in the United Kingdom.

In this lecture I propose to say something about the likely impact of Brexit on United Kingdom domestic law, the legal system and United Kingdom legal thinking. Before doing so, however, I must say something about the principal features of the EU system because an understanding of the nature and complexity of EU law and the extent to which it is integrated into the domestic law of the United Kingdom is essential to an appreciation of the scale of the task of severing the link.

\section{THE EVOLUTION OF THE EUROPEAN UNION}

The organisation to which the United Kingdom acceded on 1 January 1973 - the EEC, widely known as the Common Market - was very different from that which the United Kingdom will shortly leave. ${ }^{1}$ The Treaty of Rome created a common market and customs union by removing tariffs and

* I gratefully acknowledge the help provided by my Judicial Assistants, Esther Drabkin-Reiter, in the preparation of this lecture, and Ewan McCaig, in its preparation for publication.

1 In 1973 the United Kingdom acceded to three treaties: Treaty Establishing the European Economic Community 298 UNTS 11 (opened for signature 25 March 1957, entered into force 1 January 1958) [Treaty 
quotas and encouraging free movement of the economic factors of production: goods, workers, capital and services, and the freedom to establish businesses abroad. ${ }^{2}$ It also established certain joint policies, including a common agricultural policy, trade policy and transport policy. ${ }^{3}$ The impact on the United Kingdom legal system of accession to the EEC was therefore relatively low. The necessary modifications to domestic law in order to align it with EEC law were relatively modest.

The nature and structure of the organisation evolved thereafter through successive treaties effecting fundamental changes. ${ }^{4}$ They increased the areas of competence of the EEC, which later became the European Community and finally the EU. For example, in 1987 the Single European Act extended the areas of competence to include cooperation in economic and monetary union, social policy, economic and social cohesion, research and technological development, and environmental policy. ${ }^{5}$ The Maastricht Treaty of 1992 created the EU and introduced the concept of European citizenship. Over time, EU competence was extended to cover certain aspects of areas such as foreign and security policy, public health and consumer protection. ${ }^{6}$ As a result, in more recent times new Member States have had to accept into their own legal systems a vastly greater body of EU law, described as the acquis communautaire, and accession processes are now much more protracted.

Since the accession of the United Kingdom, the membership of the organisation has expanded massively. The original six members of the EEC - West Germany, France, Italy, Belgium, the Netherlands and Luxembourg - were joined by the United Kingdom, Ireland and Denmark in 1973.

of Rome]; Treaty Instituting the European Coal and Steel Community 261 UNTS 140 (opened for signature 18 April 1951, entered into force 23 July 1952) [ECSC]; and Treaty establishing the European Atomic Energy Community 298 UNTS 167 (opened for signature 25 March 1957, entered into force 1 January 1958) [EURATOM].

The ECSC was a forerunner of the EEC, established in an attempt to help reconstruct the economies of the continent and to regulate the coal and steel industries so as to prevent another catastrophic war in Europe. It provided that it would expire after 50 years and, in the event, was then subsumed within the EU.

2 Paul Craig and Gráinne de Búrca EU Law: Text, Cases, and Materials (6th ed, Oxford University Press, Oxford, 2015) at 4-5.

3 Treaty of Rome, above n 1, art 3.

4 Single European Act [1987] OJ L169/1 (signed 28 February 1986, entered into force 1 July 1987); Treaty on European Union [1992] OJ C191/1 (signed 7 February 1992, entered into force 1 November 1993) [Maastricht Treaty]; Treaty of Amsterdam amending the Treaty on European Union, the Treaties Establishing the European Communities and Certain Related Acts [1997] OJ C340/1 (signed 2 October 1997, entered into force 1 May 1999); Treaty of Nice amending the Treaty on the European Union, the Treaties Establishing the European Communities and Certain Related Acts [2001] OJ C80/1 (signed 26 February 2001, entered into force 1 February 2003); and Treaty of Lisbon amending the Treaty on European Union and the Treaty establishing the European Community [2007] OJ C306/1 (signed 13 December 2007, entered into force 1 December 2009) [Treaty of Lisbon].

5 Craig and de Búrca, above n 2, at 9.

6 Treaty of Lisbon, above $\mathrm{n} 4$. 
Since then it has more than trebled in size. ${ }^{7}$ In particular after the demise of the Soviet Union many former communist states in Central and Eastern Europe joined. The reunited Germany was integrated into the Union. Today there are 28 members of the EU including the United Kingdom.

The EU is essentially treaty-based and intended to integrate various activities among the Member States. The scope and the degree of intensity of integration have been modified as one treaty has succeeded another. Treaties have been described as overworked instruments of international law. In particular, they perform the role of contracts, law making treaties provide a means of legislating for the contracting states and treaties also provide the constitutive basis of international organisations. In the evolution of the EU it is possible to detect features of very different treaty regimes. The EEC was originally a treaty-based free trade area. (Treaty-based customs unions have, of course, long been familiar in international law.) Yet it also had many of the features of an international organisation created by treaty including intergovernmental organs: a Commission, a Council, a Court of Justice and an Assembly, which later became the European Parliament. Increasingly, it has developed features which are often associated with federalism. The Commission, the directly elected European Parliament and the Court of Justice of the European Union (CJEU) are supranational organs in the sense that they transcend Member States' interest. Of the 28 Member States, 19 have entered into an economic and monetary union with a common currency. It has a Charter of Fundamental Rights ${ }^{8}$ and it has a pan-European citizenship, although founded on national citizenship.

It is a markedly legal project and it is underpinned by certain fundamental principles which may be described as federal or federative. The Treaties establish categories of Union competence divided into exclusive and shared competence. In areas outside its competence the Union has only a supportive or supplementary role. ${ }^{9}$ The principle of sincere cooperation requires the Member States to assist each other in carrying out tasks which flow from the Treaties. ${ }^{10}$ The principle of conferral establishes that the Union can act only within the competences conferred on it (the others remain with the Member

7 Other countries joined as follows: Greece, 1981; Spain and Portugal, 1986; Austria, Finland and Sweden, 1995; Cyprus, the Czech Republic, Estonia, Hungary, Latvia, Lithuania, Malta, Poland, Slovakia and Slovenia, 2004; Bulgaria and Romania, 2007; and Croatia, 2013.

8 Charter of Fundamental Rights of the European Union [2012] OJ C326/391 (first "solemnly proclaimed" by the European Parliament, European Council and European Commission on 7 December 2000 and solemnly proclaimed anew on 12 December 2007, entered into force 1 December 2007 by virtue of art 6(1) of the Treaty of Lisbon, above $\mathrm{n} 4$, stipulating that the Charter has the "same legal value as the Treaties").

9 Consolidated Version of the Treaty on the Functioning of the European Union [2012] OJ C326/47 [TFEU], art 2 .

10 Consolidated Version of the Treaty on European Union [2012] OJ C326/13 [TEU], art 4(3). 
States) ${ }^{11}$ there is an analogy here with the 10 th Amendment to the United States Constitution. ${ }^{12}$ The principle of subsidiarity means that in areas outside its exclusive competence the Union shall act only if and in so far as the objectives of the action cannot be sufficiently achieved by the Member States or can be better achieved at the Union level. ${ }^{13}$ The principle of proportionality is intended to secure that the content and form of Union action shall not exceed what is necessary to achieve the objectives of the Treaties. ${ }^{14}$ The EU has a power to take action to harmonise Member State provisions affecting the internal market ${ }^{15}$ and a flexibility provision enables the Union, if necessary, to act to attain one of the Treaties' objectives where the Treaty has not provided the necessary powers to do so. ${ }^{16}$

Yet the EU lacks the classic component elements of a nation state. Even if it can be regarded as having a single people, the concept of European citizenship is dependent on the grant of citizenship by a Member State. It has no army or police force. It has very limited powers of direct taxation. Moreover, there is no shared vision among the peoples of the Member States of the EU as a unified, constitutionalised political community, ${ }^{17}$ notwithstanding the objective from the outset of the project of "ever closer union".

We are not here concerned simply with the obligations of states on the international plane. Far from being a specific application of public international law, the EU has created its own internal legal system. A striking feature of the EU project, right from the start, has been the critical role played by the ECJ (now the CJEU) in inventing and developing a distinctive EU legal order which enables the EU to function. Over the years this has become immensely complex and its many internal subject areas have become areas requiring a high degree of specialisation by academic and practitioner lawyers alike. The EU legal order has permeated the domestic law of its Member States. From a very early stage - even before the accession of the United Kingdom - two fundamental principles were firmly established. The first is the principle of the direct effect of EU law, the result of which is that

11 Article 5 of the TEU states:

1. The limits of Union competences are governed by the principle of conferral. The use of Union competences is governed by the principles of subsidiarity and proportionality.

2. Under the principle of conferral, the Union shall act only within the limits of the competences conferred upon it by the Member States in the Treaties to attain the objectives set out therein. Competences not conferred upon the Union in the Treaties remain with the Member States.

12 "The powers not delegated to the United States by the Constitution, nor prohibited by it to the States, are reserved to the States respectively, or to the people."

13 TFEU, above n 9, art 5(3).

14 TEU, above n 10, art 5(4).

15 Article 113.

16 Article 352. Compare the "necessary and proper" clause in the United States Constitution, art I, $\S 8, \mathrm{cl} 18$.

17 See for example the French and Dutch rejection of the European Constitution in 2005. 
those provisions of EU law that meet the requirements for direct effect confer rights on individuals that they may enforce before national courts. In this way all national courts have become EU courts. ${ }^{18}$ The second is the principle of the supremacy of EU law over national law. In Costa $v$ ENEL, the ECJ derived this principle from that of direct effect which, it explained, would be meaningless if a Member State could unilaterally nullify its effect by national legislation. ${ }^{19}$ It concluded that the Treaty of Rome was an independent source of law which could not be overridden by domestic legal provisions.

On the accession of the United Kingdom, Parliament enacted the European Communities Act 1972 in order to give effect to EEC law within the United Kingdom. The impact of EU law on the domestic law of the United Kingdom over the last 45 years has been immense. In a particularly prescient figure of speech, Lord Denning MR in HP Bulmer Ltd v Bollinger in 1974, one of the early cases on EEC law to come before the Court of Appeal of England and Wales, described this new body of law as an incoming tide, flowing into the estuaries and up the rivers of the United Kingdom. ${ }^{20}$ "It cannot be held back", he said. Even he can have had no idea of the scale of the changes which would be effected to domestic law as the scope of EU law developed.

The EU operates on a principle of conferred competence: it may only make laws in areas where competence has been conferred by Member States, as provided for in the Treaties of the European Union. ${ }^{21}$ Nevertheless, within these areas the scope of EU competences is vast. The EU has exclusive competence in the areas of customs union, competition and some common policies. It shares competence with Member States in areas including social policy, agriculture, consumer protection, transport and the environment. ${ }^{22}$ While the EU does not have competence to pass harmonising legislation concerning healthcare, culture, industry, education and tourism, it nevertheless has powers to adopt coordinating or supporting measures in these areas.

Some examples serve to demonstrate the breadth of EU competence. EU law has been used to challenge the limits on Sunday trading hours in the United Kingdom. ${ }^{23}$ Arguments based on the free movement of goods, services and persons under EU law have been raised in cases involving the

18 Case 26/62 NV Algemene Transport, en Expeditie Onderneming van Gend \& Loos v Nederlandse Administratie der Belastingen [1963] ECR 13 (ECJ).

19 Case 6/64 Costa v ENEL [1964] ECR 585 (ECJ).

20 HP Bulmer Ltd v J Bollinger SA [1974] Ch 401 (CA) at 418.

21 TEU, above n 10, art 5(2).

22 TFEU, above n 9, arts 3-5

23 Case C-145/88 Torfaen Borough Council v B \& $Q$ [1989] ECR 3851 (ECJ); and Case C-169/91 Stoke-onTrent City Council v $B \& Q$ [1992] ECR I-06635. 
packaging of cigarettes and industrial action by employees of train operators. ${ }^{24}$ Freezing orders applied to the assets of those with connections to oppressive regimes or terrorist organisations are subject to EU law rules on procedural rights. ${ }^{25}$ Differences in insurance premiums levied on men and women based on actuarial analysis have fallen foul of EU law, as has a failure to legislate for compensation in the case of flight delays. ${ }^{26}$

\section{EUROPEAN UNION AND EUROPEAN CONVENTION ON HUMAN RIGHTS DISTINGUISHED}

At this point I should take a moment to distinguish between EU law and the European Convention on Human Rights (ECHR). ${ }^{27}$ Acts of the United Kingdom Parliament have implanted two separate bodies of supranational law into the domestic law of the United Kingdom. As I have already mentioned, the European Communities Act introduced EEC law (now EU law) into domestic law. The Human Rights Act 1998 (UK) implemented the European Convention on Human Rights - a treaty which the United Kingdom had drafted and to which the United Kingdom had been a party since its inception - into the domestic law of the United Kingdom. Each of these systems has its own judicial organ: the EU has the CJEU with its seat in Luxembourg and the ECHR has the European Court of Human Rights in Strasbourg. This is a ripe source of confusion - not merely to the man or woman in the street who, not surprisingly, often confuses the two, but also to the BBC and others who ought to know better. The legal relationships between domestic law in the United Kingdom and these two supranational legal systems are very different:

- In the case of the EU, EU law is given effect in domestic law by the European Communities Act and it is supreme in the sense that conflicting provisions of national law, even if in primary legislation, must be disapplied. ${ }^{28}$

- By contrast, there is no power in a United Kingdom court to disapply United Kingdom legislation on the ground that it conflicts with the ECHR. The most a court can do is to grant

$24 R$ (British American Tobacco) $v$ Secretary of State for Health [2016] EWCA Civ 1182, [2018] QB 149; and Govia GTR Railway v Associated Society of Locomotive Engineers and Firemen [2016] EWCA Civ 1309, [2017] ICR 497.

25 Joined Cases C-584/10 P, C-593/10 P and C-595/10 P Kadi v European Commission ECLI:EU:C:2013:518; and Case T-200/11 Al Matri v Council of the European Union ECLI:EU:T:2013:275.

26 Case C-236/09 Association Belge des Consommateurs Test-Achats ASBL v Conseil des ministres [2011] ECR I-00773; and Joined Cases C-402/07 and C-432/07 Sturgeon v Condor Flugdienst GmbH [2009] ECR I10923.

27 Convention for the Protection of Human Rights and Fundamental Freedoms (as amended by Protocols No 11 and 14) 213 UNTS 221 (opened for signature 4 November 1950, entered into force 3 September 1953) [ECHR].

28 See generally $R v$ Secretary of State for Transport, ex parte Factortame Ltd (No 2) [1991] 1 AC 603 (HL), particularly at 658-659; and Case C-213/89 R v Secretary of State for Transport, ex parte Factortame Ltd [1990] ECR I-02433 at [17]. 
a declaration of incompatibility. ${ }^{29}$ Such a declaration has no impact on the status or validity of an Act of Parliament. ${ }^{30}$

Although distinct, these two systems overlap in various ways. In particular, although the EU is not a party to the ECHR, ECHR principles are accepted as an integral element of EU law. Furthermore, the EU has its own Charter of Fundamental Rights, many of which are identical to corresponding rights under ECHR. ${ }^{31}$ Because of the different status accorded to these supranational systems in domestic law in the United Kingdom, an individual may find that his or her reliance on an ECHR right can achieve only a declaration of incompatibility whereas his or her reliance on the identical right under the EU Charter, which has primacy, ${ }^{32}$ results in the legislation being disapplied. ${ }^{33}$ A major consequence of the United Kingdom's exit from the EU will be that United Kingdom courts will no longer have the power to disapply primary legislation.

Although the United Kingdom is withdrawing from the EU, the Government has stated that this will not affect the United Kingdom's participation in the ECHR and that there are no plans to withdraw from the ECHR. ${ }^{34}$

\section{WITHDRAWAL}

In a referendum held on 23 June 2016 a majority voted in favour of the United Kingdom withdrawing from the EU. Prior to 2009 there was no procedure under the EU Treaties for withdrawal. However, art 49A of the Treaty of Lisbon, which came into force on 1 December $2009,{ }^{35}$ introduced for the first time a procedure for a Member State to withdraw voluntarily from the EU. This is now found in art 50 of the Treaty on European Union (TEU). ${ }^{36}$ It provides that any Member State may decide to withdraw from the Union in accordance with its own constitutional requirements. The withdrawing state is required to notify the European Council of its intention. The Union and the

29 Human Rights Act 1998 (UK), ss 3-4.

30 Section 4. See also Steinfeld v Secretary of State for Education [2017] EWCA Civ 81 at [130].

31 Indeed, art 52(3) of the Charter of Fundamental Rights of the European Union, above n 8, provides: "In so far as this Charter contains rights which correspond to rights guaranteed by the Convention for the Protection of Human Rights and Fundamental Freedoms, the meaning and scope of those rights shall be the same as those laid down by the [ECHR]."

32 Case 106/77 Amministrazione delle Finanze dello Stato v Simmenthal SpA [1978] ECR 639 (ECJ) at [21].

33 Benkharbouche v Secretary of State for Foreign and Commonwealth Affairs [2017] UKSC 62.

34 "The UK's withdrawal from the EU will not change the UK's participation in the ECHR and there are no plans to withdraw from the ECHR." Department for Exiting the European Union Legislating for the United Kingdom's withdrawal from the European Union (Cm 9446, March 2017) [Legislating for the Withdrawal White Paper] at [2.22].

35 Treaty of Lisbon, above $\mathrm{n} 4$.

36 TEU, above n 10 . 
withdrawing state are then required to negotiate and conclude an agreement setting out the arrangements for its withdrawal. The EU Treaties will cease to apply to the withdrawing state from the date of coming into force of the withdrawal agreement or, failing that, two years after the deposit of the notification of intention to withdraw.

The United Kingdom Government initially took the view that it was open to it to give notice of withdrawal under art 50 pursuant to the Royal prerogative as the abrogation of a treaty was a matter for the Crown in the conduct of the foreign relations of the United Kingdom. In other words it considered that it was not necessary to obtain the prior approval of Parliament. There followed a high profile legal challenge in $R$ (Miller) $v$ Secretary of State for Exiting the European Union which resulted in a majority decision of the Supreme Court that the approval of Parliament was required. ${ }^{37}$ The Government then introduced into Parliament the European Union (Notification of Withdrawal) Bill 2017, which simply stated that the Prime Minister may notify, under art 50(2) of the TEU, the United Kingdom's intention to withdraw from the EU. ${ }^{38}$ The Bill received the Royal assent on 16 March 2017. On 29 March 2017, the Government gave notice to the European Council under art 50 of the TEU.

Negotiations for the arrangements for withdrawal have started. The stated position of the European Council is that the process of withdrawal must be approached in a linear fashion. First there must be a withdrawal agreement, then there may be temporary prolongation of existing EU membership terms or a transition agreement, if required, and finally there may be negotiated a partnership agreement with the United Kingdom, once the United Kingdom is a third country. It is only once the European Council has determined that sufficient progress has been achieved that it will allow negotiations to proceed to the next phase. Its position is that any partnership agreement will be a mixed agreement with the result that it will require the approval of all Member States. The Government has given a commitment that it will put the final agreement between the United Kingdom and the EU to a vote of both Houses of Parliament before it comes into force.

Against this background, I should now like to say something about the likely impact of Brexit on substantive law within the United Kingdom, on the legal system and on United Kingdom legal thinking. In addressing these matters I must make clear that I have nothing to say about the decision to leave the EU or what arrangements should be put in the place of United Kingdom membership. Similarly, I have nothing to say about the political issues surrounding the draft Bill. These are matters for the politicians and for the political branches of the state. It is not for me as a judge to comment on them. My interest is limited to identifying the legal effect of the changes which are likely to take place.

$37 R$ (Miller) v Secretary of State for Exiting the European Union [2017] UKSC 5, [2017] 2 WLR 583.

38 European Union (Notification of Withdrawal) Bill 2017 (UK), cl 1. 


\section{THE REPEAL OF THE EUROPEAN COMMUNITIES ACT 1972}

In March 2017, the Government published a White Paper outlining its proposals. ${ }^{39}$ More recently, on 13 July 2017, the European Union (Withdrawal) Bill, which has been nicknamed "the Great Repeal Bill", was introduced into the House of Commons. As a result we now have a clear picture of what is proposed although this will be subject to debate and possible amendment in Parliament. The following commentary is based on the Bill as introduced into the House of Commons.

The starting point is the intention to repeal the European Communities Act with effect from exit day, that being the day on which the United Kingdom leaves the EU. Clause 1 of the Bill simply provides that the 1972 Act is repealed on exit day. The 1972 Act was very skilfully drafted and sought to bring United Kingdom law into conformity with the requirements of the law of the EEC as it then was by two main methods. Section 2(1) provided:

\footnotetext{
All such rights, powers, liabilities, obligations and restrictions from time to time created or arising by or under the Treaties, and all such remedies and procedures from time to time provided for by or under the Treaties, as in accordance with the Treaties are without further enactment to be given legal effect or used in the United Kingdom shall be recognised and available in law, and be enforced, allowed and followed accordingly ...
}

This provision introduced into domestic law the body of European law which was required to have direct effect as it changed from time to time. This means that where EU legal instruments and principles are directly applicable as a matter of EU law, they become part of the body of United Kingdom domestic law without further action being necessary on the part of United Kingdom institutions. Individuals can then enforce the rights contained in those legal instruments in the English courts. Examples of such EU legislation include Regulations, which are generally applicable to all EU Member States, and Decisions, which are only applicable to those Member States to which they are addressed.

Section 2(2) conferred powers to make delegated legislation for the purpose of implementing any Community (now EU) obligation of the United Kingdom - that is, any obligation "created or arising by or under the Treaties" or "enabling any rights ... enjoyed ... by the United Kingdom under or by virtue of the Treaties to be exercised" - and for ancillary purposes. This primarily applies to Directives, which must be implemented by national legislation in order to have effect in Member States. This leaves Member States free to decide how to put into effect the rights provided for by the Directive. As a result, the Directive has often been the EU's instrument of choice for more controversial areas of legislation.

In Miller the majority of the Supreme Court explained that the 1972 Act first provided that rights, duties and rules derived from EU law should apply in the United Kingdom as part of its domestic law

39 Legislating for the Withdrawal White Paper, above n 34 
and, secondly, provided for a new constitutional process for making law in the United Kingdom. It authorised a dynamic process by which, without further primary legislation (and, in some cases, even without any domestic legislation), EU law not only became a source of United Kingdom law, but actually took precedence over all domestic sources of United Kingdom law, including statutes. It explained that this unprecedented state of affairs would only last so long as Parliament wishes. The 1972 Act can be repealed like any other statute. For that reason, the Supreme Court did not accept that the fundamental rule of recognition (the grundnorm) had been varied by the 1972 Act or would be varied by its repeal. ${ }^{40}$

Once the United Kingdom leaves the EU it will no longer be obliged as a matter of EU law to give effect to EU legislation and case law in its domestic law. However, the mere repeal of these provisions in the 1972 Act simply would not work. This would result in all directly applicable EU law no longer being applicable in the United Kingdom. It would also cause the legal basis for secondary legislation made under s 2(2) to fall away. The scope of EU law in domestic law is currently so vast that this would have the unacceptable result of leaving large gaps in the statute book. Moreover, the task of replacing it all by domestic legislation would be the work of many years.

\section{TRANSPOSITION OF THE ACQUIS}

The solution adopted by the Bill is, in the interest of legal certainty and continuity, to convert the "acquis" - the body of EU legislation - into domestic law at the point at which the 1972 Act is repealed. This approach is intended to maximise certainty and stability. It is the Government's view that, unless and until domestic law is changed by legislators in the United Kingdom, legal rights and obligations in the United Kingdom should where possible be the same after exit day as they were immediately before. It is difficult to quantify legislation. However, some idea of the scale of the undertaking can be attempted. According to EUR-Lex, the EU's legal database, there are currently over 12,000 EU regulations in force. So far as United Kingdom legislation implementing EU law is concerned, the House of Commons Library indicates that there are about 186 Acts of Parliament and 7,900 statutory instruments implementing EU law. ${ }^{41}$ So the intention is that this whole body of EU law should be retained in domestic law and that it can be amended by legislators thereafter if that is considered appropriate.

In broad terms, this transposition of the acquis will be achieved as follows. First, $\mathrm{cl} 3$ of the Bill provides that direct EU legislation - legislation which previously had direct effect by virtue of s 2(1) of the European Communities Act - so far as operative immediately before exit day, forms part of domestic law on and after exit day. The test of direct effect has been developed in the case law of the CJEU. In very general terms, a provision will be directly effective where it is "clear and

40 Miller, above n 37, at [60]-[62] per Lord Neuberger.

41 These figures exclude primary legislation and statutory instruments made by the devolved bodies in Scotland, Northern Ireland and Wales. 
unconditional", but it is often far from clear how that test should be applied in practice. This is a matter with which courts in the United Kingdom may have to grapple following exit day. ${ }^{42}$

Secondly, cl 2 of the Bill provides that EU-derived domestic legislation - including that made under s 2(2) of the European Communities Act - as it has effect in domestic law immediately before exit day, continues to have effect in domestic law on and after exit day. Thirdly, cl 4 further provides that rights which immediately before exit day are available in domestic law by virtue of s 2(1) continue on and after exit day.

The process of transposition of the acquis into domestic law is not, however, as straightforward as it might at first appear. The Government accepts that a very significant proportion of EU-derived law, even when converted into domestic law, will not achieve its desired legal effect in the United Kingdom once the United Kingdom has left the EU. ${ }^{43}$ A great deal of the legislation, if simply transposed verbatim, will not make sense or will just not work. Legislation may confer a particular role on an EU institution. In the field of competition law or environmental law there may be a requirement for certain matters to be reported to the Commission. Verbatim transposition of the legislative provision would be pointless because the Commission will no longer perform this role after exit day. Similarly, legislation may be based on United Kingdom membership or access to an EU regime or system. In the absence of such membership or access the transposed legislation simply would not work. ${ }^{44}$ As a result it will be necessary to amend much of the transposed acquis.

Amending the EU legislation in advance of exit day is a function which cannot be performed by the Repeal Bill itself. It is simply too vast a task. Moreover, the Government is under considerable time pressure. The art 50 clock is ticking. It is proposed, therefore, that this be done by delegated legislation.

The use of delegated powers to amend the acquis does create certain problems. The White Paper accepts that a fine balance is called for: ${ }^{45}$

The Government is mindful of the need to ensure that the right balance is struck between the need for scrutiny and the need for speed. This White Paper is the beginning of a discussion between Government and Parliament as to the most pragmatic and effective approach to take in this area

42 The Bill also makes provision in relation to the validity of retained EU law. Draft paragraph 1 of sch 1 provides that there is no right in domestic law on or after exit day to challenge any retained EU law on the basis that, immediately before exit day, an EU instrument was invalid. However, this does not apply so far as the CJEU has decided before exit day that the instrument is invalid or the challenge is of a kind provided for in regulations made by a minister.

43 Legislating for the Withdrawal White Paper, above n 34, at [1.14] and [3.5].

44 At [1.14].

45 At [3.23]. 
The House of Lords Select Committee on the Constitution distinguished in this regard between the more mechanical act of converting EU law into United Kingdom law, and the discretionary process of amending EU law to implement new policies in areas that previously lay within the EU's competence. ${ }^{46}$ The Committee considered that the latter should be done through primary legislation. The Government has accepted this approach and has accepted that the purpose of secondary legislation under the Repeal Bill is to convert EU law into United Kingdom law. ${ }^{47}$

In the published Bill, therefore, cl 7 provides that a minister may by regulations make such provision as the minister considers appropriate to prevent, remedy or mitigate any failure of retained EU law to operate effectively, or any other deficiency in retained EU law, arising from the withdrawal of the United Kingdom from the EU. However, the power to make regulations under this section will end two years after exit day. ${ }^{48}$

The former Lord Chief Justice, Lord Thomas, in his Scarman Lecture drew attention to the risk that when statutory instruments are used to alter the law, those adversely affected by such changes including those who consider the changes to be unscrutinised policy changes - may challenge the secondary legislation in the courts. ${ }^{49} \mathrm{He}$ made the point, very forcefully, that the courts have no interest in being drawn into "political decision-making" and expressed his concern about the courts being required to take decisions in politically contentious areas. ${ }^{50}$ The risk of this occurring can be reduced by more effective scrutiny by Parliament. He made the point that: ${ }^{51}$

It is axiomatic that the greater the level of public debate and Parliamentary scrutiny of an issue, the greater the likelihood the resulting primary or secondary legislation will be well-thought out, tested, coherent and [will] ... reflect "the widest possible consensus", such that a court is less likely to be asked to resolve policy questions.

As a result he drew attention to the many options available including the use of specific Acts, prelegislative scrutiny, the laying of statutory instruments in draft as part of the affirmative procedure, the super-affirmative procedure, the involvement of select committees and the possibility of devising new procedures to meet the unprecedented legislative challenge.

46 House of Lords Select Committee on the Constitution The 'Great Repeal Bill' and delegated powers (HL Paper 123, 7 March 2017).

47 Legislating for the Withdrawal White Paper, above n 34, at [3.10].

48 Clause 7(7).

49 Lord Thomas 'Law Reform Now' in 21st Century Britain: Brexit and Beyond (6th Scarman Lecture, Gray's Inn, 26 June 2017)

50 At [18].

51 At [20] (footnotes omitted). 
Although the Repeal Bill is not intended to make major changes to policy or establish new legal frameworks in the United Kingdom beyond those which are necessary to ensure the law continues to function effectively following exit day, the Government has announced its intention of securing, in addition, further primary legislation in advance of exit day, most notably a customs Bill which will implement a United Kingdom customs regime and an immigration Bill. The Government has stated that new legislation will be required here to implement new policies or institutional arrangements that go beyond replicating current EU arrangements in United Kingdom law. ${ }^{52}$

There will be some areas in which the United Kingdom may take a unilateral initiative. For example, it would be open to the United Kingdom to enact in national law EU rules on choice of law in contract and tort, currently contained in the Rome I and Rome II Regulations. ${ }^{53}$ After exit day it would be possible to re-enact these in a modified form in order to reflect domestic policy objectives. The former Lord Chief Justice has suggested that there may be a role here for the Law Commission. ${ }^{54}$ However, there are other areas where unilateral action by the United Kingdom simply cannot provide a solution. An example is the Brussels Regulation governing jurisdiction and enforcement of judgments in civil and commercial matters. ${ }^{55}$ As this turns on reciprocal obligations between states, a new international agreement will be required here. This will be vital in order to maintain the present status of London as a leading centre for dispute resolution but will also be in the interests of the other Member States. Another example is the EU scheme governing the European Arrest Warrant which governs extradition within the EU and which will also need to be replaced. ${ }^{56}$

\section{SUPREMACY OF EUROPEAN UNION LAW}

So long as the United Kingdom remains a member of the EU, EU law is supreme within the United Kingdom. That is required by EU law and achieved by the European Communities Act. The consequences which follow from this include the following. ${ }^{57}$ United Kingdom courts are obliged to interpret EU Treaties, Regulations and Directives in accordance with decisions of the Court of Justice. They are obliged to refer unclear points of EU law to the Court of Justice. They are obliged to interpret all domestic legislation, if at all possible, so as to comply with EU law (the Marleasing obligation). ${ }^{58}$

52 Legislating for the Withdrawal White Paper, above n 34, at [1.21]-[1.22].

53 Regulation 593/2008 on the law applicable to contractual obligations (Rome I) [2008] OJ L177/6; and Regulation 864/2007 on the law applicable to non-contractual obligations (Rome II) [2007] OJ L199/40.

54 Lord Thomas, above $\mathrm{n} 49$.

55 Regulation 1215/2012 on jurisdiction and the recognition and enforcement of judgments in civil and commercial matters [2012] OJ L351/1.

56 Council Framework Decision 2002/584/JHA on the European arrest warrant and the surrender procedures between Member States [2002] OJ L190/1.

57 Miller, above n 37, at [64]-[67] per Lord Neuberger.

58 Case C-106/89 Marleasing v La Comercial Internacional de Alimentacion SA [1990] ECR I-4135. 
Legislation which is inconsistent with EU law from time to time is to that extent ineffective in law. Any serious breach by the United Kingdom Parliament, government or judiciary of any rule of EU law intended to confer individual rights will entitle any individual sustaining damage as a direct result to compensation from the United Kingdom Government (the Francovich/Brasserie du Pêcheur cause of action). ${ }^{59}$

Furthermore, because the European Communities Act has in domestic law a constitutional character, as a matter of domestic law EU law cannot be implicitly displaced by the mere enactment of legislation which is inconsistent with it. ${ }^{60}$

However, the Repeal Bill, which once enacted will also have the status of a constitutional statute, will now expressly repeal the European Communities Act. The intention is that where new primary legislation enacted after exit day conflicts with EU-derived law, the new legislation will take precedence over EU-derived law. The White Paper explains that in this way the Repeal Bill will end the general supremacy of EU law. As Lord Neuberger put it in Miller ${ }^{61}$

... those legal rules derived from EU law and transposed into UK law by domestic legislation will have a

different status. They will no longer be paramount, but will be open to domestic repeal or amendment in ways that may be inconsistent with EU law.

However, the status of a preserved rule of EU law may well depend on the principle of supremacy. For example, the validity of a regulation made before exit day in order to implement EU law may depend on the fact that it prevails over later legislation also made before exit day. In order to maintain certainty and continuity in the law, therefore, the principle of supremacy is retained to a limited extent. Accordingly, cl 5(1) provides that the principle of the supremacy of EU law does not apply to any enactment or rule of law passed or made on or after exit day. However, it then goes on to spell out certain consequences of that provision: ${ }^{62}$

Accordingly, the principle of the supremacy of EU law continues to apply on or after exit day so far as relevant to the interpretation, disapplication or quashing of any enactment or rule of law passed or made before exit day.

59 Joined Cases C-6/90 and C-9/90 Francovich and Bonifaci v Italy [1991] ECR I-5357; Joined Cases C-46/93 and C-48/93 Brasserie du Pêcheur SA v Germany [1996] ECR I-1029; and $R v$ Secretary of State for Transport, ex parte Factortame Ltd (No 4) [1996] QB 404. This cause of action is abolished by draft paragraph 4 of sch 1 to the European Union (Withdrawal) Bill.

60 Thoburn v Sunderland City Council [2002] EWHC 195 (Admin), [2003] QB 151 at [37]-[47] per Laws LJ; and Miller, above n 37, at [66] per Lord Neuberger.

61 Miller, above n 37, at [80].

62 Clause 5(2). 
The result is that where a conflict arises between pre-exit domestic legislation and retained EU law, the principle of supremacy will, where relevant, continue to apply as it did before exit. So a retained EU regulation would take precedence over pre-exit domestic legislation that is inconsistent with it. ${ }^{63}$

A further consequence of these provisions is that the current requirement that domestic law must be interpreted, as far as possible, in light of the wording and purpose of relevant directives - the Marleasing obligation - will not apply to domestic legislation passed or made on or after exit day, but it will continue to apply to domestic legislation passed or made before exit day. Moreover, the Francovich/Brasserie du Pêcheur cause of action is abolished by sch 1 of the Repeal Bill.

\section{CHARTER OF FUNDAMENTAL RIGHTS}

It is not my intention to provide a comprehensive account of the detail of the Bill. That would be tedious. In any event, the detail of its clauses is likely to change during its passage through Parliament. However, I should draw attention to one area of directly effective EU law which the Government proposes shall not be transposed into domestic law. That is the Charter of Fundamental Rights. This has been unpopular with successive United Kingdom governments since its birth.

Clause 5(4) of the Repeal Bill provides that the Charter is not part of domestic law on or after exit day. The Government's position on this is that the Charter only applies to EU states when acting within the scope of EU law, so its relevance is removed by withdrawal from the EU. However, it accepts that the Charter did not create any new rights, but rather codified rights and principles which already existed in EU law. Its intention is, therefore, that those underlying rights and principles will be converted into domestic law by the Bill. Accordingly, cl 5(5) goes on to provide that this does not affect the retention in domestic law on or after exit day of any fundamental rights or principles which exist irrespective of the Charter.

\section{CASE LAW OF THE COURT OF JUSTICE OF THE EUROPEAN UNION}

A particularly difficult aspect of the future relationship between domestic law and EU law, and a matter of particular concern to the judiciary in the United Kingdom, is the status after exit day of decisions of the CJEU. On the one hand, the Government is acutely aware of the need to provide legal continuity and certainty following exit day. On the other, one of the main planks of the Vote Leave campaign was the need to break the link between the CJEU and the United Kingdom courts and, as they put it, to "take back control" of the laws and legal regulation of the United Kingdom. Once again, the particular concern here is that legislation should define the precise legal status of judgments of the Luxembourg Court in order to relieve judges of having to decide the matter for themselves. In the

63 Furthermore, $\mathrm{cl} 5(3)$ provides that the principle of supremacy can continue to apply to pre-exit law which is amended on or after exit day where that accords with the intention of the modifications. 
light of the "enemies of the people" episode following the decision of the Divisional Court in the Miller case, it is perhaps not surprising that this is a matter of considerable sensitivity.

In her evidence to the House of Lords Constitution Committee, Baroness Hale, the then Deputy President of the Supreme Court, said: ${ }^{64}$

... one major concern that we have in the [Supreme Court], and probably throughout the judiciary, is that it should be made plain in statute what authority or lack of authority, or weight or lack of weight, is to be given to the decisions of the Court of Justice of the European Union after we have left, in relation both to matters that arose before we left and, more importantly, to matters after we leave. That is not something we would like to have to make up for ourselves, obviously, because it is very much a political question, and we would like statute to tell us the answer.

The Government's position has been that on leaving the EU the jurisdiction of the CJEU over the United Kingdom will come to an end. However, as long as EU-derived law remains on the United Kingdom statute book, it is essential that there be a common understanding of what that law means. The Government considers that this is best achieved by providing for continuity in how that law is interpreted before and after exit day. To maximise certainty, therefore, it is intended that any question as to the meaning of EU-derived law will be determined in the United Kingdom courts by reference to the CJEU's case law as it exists on exit day. ${ }^{65}$

The Bill now provides a welcome degree of clarity on this issue - at least in relation to pre-exit case law.

\section{PRE-EXIT CASE LAW}

In the case of decisions of the CJEU made prior to exit day, cl 6(3) establishes that, in general, any question as to the validity, meaning or effect of any retained EU law is to be decided, so far as that law is unmodified on or after exit day, in accordance with any retained case law - that is, any principles laid down by and any decisions of the CJEU as they have effect in EU law immediately before exit day. However, cl 6 also provides that the Supreme Court (and the High Court of Justiciary in Scotland) are not bound by any retained EU case law. ${ }^{66}$ In this regard it provides that in deciding whether to depart from any retained EU case law, the Supreme Court or the High Court of Justiciary must apply the same test as it would apply in deciding whether to depart from its own case law. In the case of the Supreme Court this is a reference to the Practice Statement of 1966 in which the Judicial Committee of the House of Lords stated that it would modify its practice and, while treating former

64 Lord Neubeuger and Baroness Hale "Uncorrected oral evidence: with the President and Deputy President of the Supreme Court" (evidence given to the Select Committee on the Constitution, 29 March 2017) at 3.

65 Legislating for the Withdrawal White Paper, above n 34, at [2.12]-[2.14].

66 Clause 6(4)(a). 
decisions of the House as normally binding, would depart from a previous decision "when it appears right to do so". 67

The White Paper observes that it is very rare for the Supreme Court to depart from one of its earlier decisions, or one of the House of Lords. ${ }^{68}$ In fact, it did so three times in 2016. However, it is likely that the Supreme Court will exercise this power sparingly. In this way the provision may achieve a balance between the need to apply transposed EU legislation in accordance with the pre-exit Luxembourg case law interpreting it and the need to avoid fossilising past decisions of the CJEU in domestic law in perpetuity. It will, of course, also be open to Parliament to change by legislation the retained case law of the CJEU.

\section{POST-EXIT CASE LAW}

So far as post-exit case law is concerned, the position is very different. Clause 6(1) of the Bill provides that a court of tribunal is not bound by any principles laid down, or any decisions made, on or after exit day by the CJEU. Clause 6(2) then states:

A court or tribunal need not have regard to anything done on or after exit day by the European Court,

another EU entity or the EU but may do so if it considers it appropriate to do so.

In these circumstances, it is left open to the court to decide in its discretion whether to have regard to Luxembourg case law. Contrary to the hope expressed by Baroness Hale, there is no further guidance forthcoming. It will be interesting to see what line the courts take. There may well be occasions on which the CJEU has, after exit day, interpreted a provision of EU law which is the parent and the exact counterpart of a rule transposed into domestic law. In these circumstances, it may well be appropriate to have regard to what has been decided, but that decision will certainly not be binding on the national court.

This is a matter of serious concern to the judiciary. In an interview with the BBC Lord Neuberger said: 69

If [the Government] doesn't express clearly what the judges should do about decisions of the ECJ after

Brexit, or indeed any other topic after Brexit, then the judges will simply have to do their best ... But to

blame the judges for making the law when Parliament has failed to do so would be unfair ...

Referring in particular to the provision in the Bill in relation to post-Brexit decisions of the CJEU he said:

67 Practice Statement (Judicial Precedent) [1966] 1 WLR 1234 (HL).

68 Legislating for the Withdrawal White Paper, above n 34, at [2.16]-[2.17].

69 Clive Coleman "UK judges need legal clarity after Brexit - Lord Neuberger" (8 August 2017) BBC News <www.bbc.com>. 
[All judges] would hope and expect Parliament to spell out how the judges would approach that sort of issue after Brexit, and to spell it out in a statute ... If the UK Parliament says we should take into account decisions of the ECJ then we will do so ... If it says we shouldn't then we won't. Basically we will do what the statute says.

\section{THE SYSTEM OF REFERENCES ENDS}

A major change in the architecture of the United Kingdom's legal system will be that following the United Kingdom's withdrawal from the EU there will, of course, be no further preliminary references from national courts to the CJEU in Luxembourg.

At the creation of the EEC it was thought that, instead of a system of appeals to the EEC Court on issues of EEC law, it was preferable - no doubt it was considered more palatable - to have a system of references from national courts on preliminary points of law. (It bears some resemblance to a case stated in domestic law whereby an inferior tribunal can be required to state a case on a point of law for consideration by a Divisional Court of the High Court.) Subject to certain exceptions, a reference may be made by any court or tribunal within the legal system of a Member State asking the CJEU to answer certain questions of EU law the answers to which are necessary for the determination of the national proceedings. A court of final appeal, usually the Supreme Court in the case of the United Kingdom, is, however, required to make a reference to Luxembourg on a disputed point of EU law unless the answer is acte clair or, in other words, unless the answer is obvious. The effect is much the same as an appeal because the ruling of the CJEU on a point of law is binding on the national court.

This system of references has enabled the CJEU to develop EU law. It also gives it a considerable degree of control so as to ensure that EU law is applied consistently within Member States. It can be a cumbersome process. On average it takes about two years from the making of the reference to the receipt of the judgment. I recently made a reference in a case where the procedure was expedited and that took some nine months. Courts in the United Kingdom have, in recent years, made about 20 references a year. In 2016 they made 23 references. Some other Member States are much more enthusiastic in using the procedure. In 2016, Italy made 47 and Germany, 84.

Clause 6(1)(a) of the Repeal Bill provides that a court or tribunal cannot refer any matter to the European Court on or after exit day. Because of the length of time a reference takes, it will be necessary to make transitional provision for references in the system on exit day. That will be a matter for the negotiations. Nevertheless, references are still being made. In particular, as long as the United Kingdom remains a member of the EU the Supreme Court will be under a duty to do so unless the issue is acte clair.

\section{INTERPRETATION OF TRANSPOSED LAW}

Following withdrawal from the EU, the body of EU law which will have been transposed into domestic law and the saved EU-derived domestic legislation will be interpreted solely by domestic courts. There will no longer be access to the Court of Justice through the preliminary ruling procedure. 
How then are domestic courts to set about the task of interpreting this transposed body of domestic law?

Clause 6(3) of the Repeal Bill provides that any question as to the validity, meaning or effect of any retained EU law is to be decided, so far as that law is unmodified on or after exit day and so far as relevant, in accordance with any retained case law and any retained general principles of EU law. "Retained general principles of EU law" is defined as meaning such general principles as have effect in EU law immediately before the exit day. ${ }^{70}$ It seems, therefore, that this is intended to import into domestic law, for this purpose, EU law principles of interpretation of legislation. These principles include adopting a purposive approach to interpretation, interpreting the legislation in the light of the purpose it is intended to achieve, ascertained, for example, from the treaty base of the legislation and the recitals within the legislation. They include a more extensive use of travaux preparatoires than the United Kingdom is used to domestically. They also include consideration of compatibility with the Treaties and general principles of EU law such as proportionality, fundamental rights and nonretroactivity.

The Treaties are the primary source of EU law and play an important role in the interpretation of legislation. The White Paper expressly makes the point that, while much of the content of the Treaties will become irrelevant once the United Kingdom leaves the EU, the Treaties (as they exist at the time of exit) may assist in the interpretation of transposed EU law. Thus, in interpreting an EU measure it will often be appropriate to have regard to its aim and content as revealed by its legal basis which is to be found in the Treaties. The example it gives is a case where in interpreting workers' annual leave entitlement, the legal basis of the Working Time Directive was found to be relevant and led to the conclusion that Member States could not adopt national rules under which workers' rights to paid annual leave depended on their having completed a minimum period of employment with the same employer. ${ }^{71}$ It is made clear in the White Paper that following exit day, courts in the United Kingdom will still be able to look to the treaty provisions in interpreting retained EU law. ${ }^{72}$

The application of EU law principles of interpretation to retained EU law may well prove challenging: not least because the transplantation of the EU acquis will result in law designed to be applied within the EU being applied in a very different context. EU legislation is intended to achieve the purposes of the Union. However, those purposes may make far less sense when the law is transferred to a purely domestic context.

70 Clause 6(7).

71 Case C-173/99 $R v$ Secretary of State for Trade and Industry, ex parte Broadcasting, Entertainment, Cinematographic and Theatre Union [2001] ECR I-4881. See also Directive 2003/88/EC concerning certain aspects of the organisation of working time [2003] OJ L299/9.

72 At [2.10]. 
These issues relating to the interpretation of the transposed acquis of EU law may well generate litigation and it is to be hoped that the judiciary can avoid being drawn into areas of controversy where they are asked to supplement the meaning of loosely drafted laws by reference to purposes which are not the purposes of domestic law within the United Kingdom.

\section{IMPACT OF THE EUROPEAN UNION ON LEGAL THINKING IN THE UNITED KINGDOM}

Although England has for centuries lived alongside a civil law system in Scotland, ${ }^{73}$ the accession of the United Kingdom to the EEC in 1973 suddenly exposed the common law system of England and Wales to the formidable influence of continental civil law systems. The United Kingdom was not a founder member of the EEC. By the date of United Kingdom accession the foundations of what was to become EU law and the procedures of the Court of Justice were already firmly established and it was inevitable that they should be dominated by features derived from civil law systems. There can be little doubt that over the last 45 years since the United Kingdom accession, EU legal doctrine and that of other EU Member States has exerted a profound influence on legal thinking within the United Kingdom. Moreover, judges, legal practitioners and academics in the United Kingdom have had many more opportunities to learn from the legal systems of the EU and other Member States. The interaction between the different legal systems and judicial authorities within the EU has resulted in a mutual exchange of ideas which has been described as a kind of osmosis between legal systems ${ }^{74}$ or the "downloading" and "uploading" of legal principles. ${ }^{75}$

The influence of EU law on domestic law within the United Kingdom has been immense. For example, when reviewing legal situations which fall within the scope of EU law, judges in Member States are obliged to apply principles of judicial review developed by the CJEU. These "general principles of EU law" include proportionality, legal certainty, legitimate expectations, nondiscrimination and procedural rights. They not only extend to the review of state action falling within the scope of EU law, but may in some circumstances also apply to the actions of private individuals or organisations, for example when undertaking strike action. ${ }^{76}$ It will often happen that a case

73 More accurately, Scotland has a "mixed" legal system. The expression "mixed system" is used by comparative lawyers to describe those systems in which there are combined major features from the two main legal traditions: common law and civil law. Scotland has had a mixed system since before the Act of Union with England in 1707. See Gloag and Henderson The Law of Scotland (14th ed, W Green, Edinburgh) at [1.19].

74 Søren Schøoenberg Legitimate Expectations in Administrative Law (Oxford University Press, Oxford, 2000) at 27.

75 Philippe Boymans and Mariolina Eliantonio "Europeanization of Legal Principles? The Influence of the CJEU'S Case Law on the Principle of Legitimate Expectations in the Netherlands and the United Kingdom" (2013) 19 EPL 715 at 715-716.

76 Case C-438/05 International Transport Workers' Federation v Viking Line ABP [2007] ECR I-10779; and Case C-341/05 Laval un Partneri Ltd v Svenska Byggnadsarbetareförbundet [2007] ECR I-11767. 
involves claims falling both within and outside the scope of EU law. As a result, judges can be called on to apply general principles of EU law and common law principles of judicial review alongside each other. ${ }^{77}$ Inevitably, this has led to EU law exerting an influence over the development of the common law.

The gradual recognition by courts in the United Kingdom that substantive legitimate expectations can be protected by English common law is an example of the influence of EU law on domestic legal thinking. ${ }^{78}$ As Lord Mackenzie Stuart observed in 1987: $:^{79}$

The concept of recognising that a failure to respect legitimate expectations may give rise, in public law,

to a remedy is a novelty in English law and lacks discernible English parentage. To find the true ancestry

one does not have to look far beyond the Channel.

In a parallel development, in some instances courts in the United Kingdom have applied the same or very similar principles in human rights cases under the Human Rights Act. For example, both EU law and ECHR employ proportionality as a standard of review, although - as the Supreme Court has recently demonstrated in $R$ (Lumsdon) $v$ Legal Services Board - their respective concepts of proportionality differ in certain important respects. ${ }^{80}$ This has prompted a lively debate among academics and practitioners as to whether proportionality should operate as a freestanding head of judicial review in domestic law in the United Kingdom, even outside the context of EU law or the rights protected by the European Convention. This step has not yet been taken. Nevertheless, the Supreme Court in $R$ (Keyu) $v$ Secretary of State for Foreign and Commonwealth Affairs has recently recognised the need for a definitive judicial answer, one way or the other, to this debate. ${ }^{81}$

Despite the immense personal contribution of individual British judges and advocates general to the development of EU law - Gordon Slynn, Francis Jacobs and Eleanor Sharpston in particular spring to mind here - the influence of the common law on EU law has, I must accept, been much more limited. However, the subtle influence of the English common law has been recognised by some academic commentators. Professor Paul Craig has observed that "the judicial development of

77 See for example United Kingdom Association of Fish Producer Organisations v Secretary of State for Environment, Food and Rural Affairs [2013] EWHC 1959 (Admin).

$78 R v$ North and East Devon Health Authority, Ex parte Coughlan [2001] QB 213 (CA); and R (Patel) v General Medical Council [2013] EWCA Civ 327.

79 Lord Mackenzie Stuart "Recent developments in English administrative law - The Impact of Europe?" in Francesco Capotorti and others (eds) Du Droit International au Droit de l'Intégration: Liber Amicorum Pierre Pescatore (Nomos Verlagsgesellschaft, Baden-Baden, 1987) at 417.

$80 R$ (Lumsdon) v Legal Services Board [2015] UKSC 41, [2016] AC 697.

$81 R($ Keyu) $v$ Secretary of State for Foreign and Commonwealth Affairs [2015] UKSC 69, [2016] AC 1355 at [132] per Lord Neuberger and at [271] per Lord Kerr. As for proportionality in New Zealand, see Claudia Geiringer "Sources of Resistance to Proportionality Review of Administrative Power under the New Zealand Bill of Rights Act" (2013) 11 NZJPIL 123. 
fundamental rights within EU law bore many of the hallmarks of 'common law' reasoning, being incremental and analogical" and that the catalyst for the recognition of process rights in EU law was in part the common law precepts of natural justice. ${ }^{82}$ The system of "precedent" in EU law developed by the Court of Justice also bears a greater similarity to the common law, which relies on reasoning by analogy from case to case, than to civil law systems which are focused on abstract rules, although, most regrettably, this is frequently reflected in the jurisprudence of the Court of Justice by a verbatim recitation of passages from earlier decisions. (I would add, in passing, how much I regret that the Court of Justice has not learnt from the United Kingdom the value of oral hearings or of dissenting judgments.)

It is fashionable at the moment to speak of a dialogue between the courts. There has certainly been a most effective dialogue between the United Kingdom Supreme Court and the European Court of Human Rights in Strasbourg to which the Strasbourg Court has on a number of occasions been very responsive. This is facilitated by the fact that decisions of the Strasbourg Court are not binding on courts in the United Kingdom; they are simply required to take them into account. In the case of the CJEU the balance is rather different as its decisions are binding on national courts. Nevertheless, the preliminary ruling procedure does provide an opportunity for the referring national court to set out its views on the issues of EU law under consideration.

There are less formal opportunities for dialogue. Judges of Member State courts and the EU courts meet through judicial collaboration bodies such as the European Judicial Network and exchange programmes whereby judges of EU Member States spend time observing court hearings in other Member States. Pan-European universities supported by the EU such as the European University Institute in Florence and the College of Europe in Bruges enable European legal academics and law students to come together to share learning in EU and Member State law before returning to their home states or taking up posts in European institutions to apply this knowledge and experience.

In a similar way, civil servant positions in the Legal Services of the European institutions permit interaction and exchange of ideas between lawyers with experience of both EU law and the domestic law of their home State. Within the United Kingdom, EU law departments in universities across the country - EU law is currently a compulsory subject for undergraduate law students - are staffed by legal academics from many different EU Member States who contribute to the multi-jurisdictional, multi-lingual character of EU law teaching. This is further supported through opportunities for study exchanges between United Kingdom and EU students under the Erasmus programme. Publications by legal academics contribute to domestic legal thinking and have the potential to influence judicial decision-making, while the students of today become the solicitors, barristers, judges and law-makers of the future.

82 Paul Craig UK, EU and Global Administrative Law (Cambridge University Press, Cambridge, 2015) at 376377. 
What will happen after Brexit? The former Lord Chief Justice recently observed that one potential consequence of a failure to keep pace with developing legal ideas on the continent of Europe may be that the United Kingdom's reputation as a frontrunner in providing and exporting legal services will be threatened, particularly in the context of the rapid changes to our world brought about by digital developments. ${ }^{83}$ I doubt that this is very likely. A whole generation of lawyers has known nothing other than a domestic legal system which is deeply imbued with the influence and concepts of EU law. These have become ingrained in United Kingdom legal thinking and such habits are now unlikely to be lost. A working knowledge of EU law will still be required in order to navigate the post-Brexit settlement incorporating the EU acquis. Although it is the Government's intention that that should, in due course, be amended, that is likely to take some time. Moreover, the United Kingdom remains party to the ECHR which will continue to exert its influence over domestic law, in particular public law.

\section{CONCLUSION}

As the United Kingdom prepares to leave the EU, domestic law within the United Kingdom faces an unprecedented challenge: to disengage EU law and the law of the United Kingdom without disrupting legal certainty and continuity. There can be no doubt that the coming years will be a time of immense change. In particular the transposition of the acquis - virtually the entire body of directly effective EU law - into domestic law will be a massive undertaking. And yet EU law will continue to have a significant influence on domestic law for some time. A substantial part of domestic law will be unintelligible without an understanding of EU law and the settlement which is now reached. It will not be possible to interpret retained EU law without a command of principles of EU law. Similarly, it will not be possible to understand the status of retained EU law without an understanding of the modifications now made to the principle of supremacy. It is, of course, open to Parliament to amend the retained EU law, but it will take a long time to do so. The United Kingdom's 45 year-long dalliance with the EU and European law may almost be over, but it will leave a lasting impression on United Kingdom domestic law.

83 Lord Thomas, above n 49, at [8]-[9]. 
